\title{
Post-cataract Cystoid Macular Oedema Prevention - Update 2019
}

\author{
Andrzej Grzybowski, ${ }^{1,2}$ Reda Zemaitiene, ${ }^{3}$ Lina Mikalauskiene ${ }^{3}$ \\ 1. Department of Ophthalmology, University of Warmia and Mazury, Olsztyn, Poland; 2. Institute for Research in Ophthalmology, \\ Foundation for Ophthalmology Development, Poznan, Poland; 3. Department of Ophthalmology, Medical Academy, \\ Lithuanian University of Health Sciences, Kaunas, Lithuania
}

DOl: https://doi.org/10.17925/EOR.2019.13.1.37

\section{Keywords}

Pseudophakic cystoid macular oedema, post-operative inflammation, cataract surgery, nonsteroidal anti-inflammatory drugs

Disclosure: Andrzej Grzybowski, Reda Zemaitiene and Lina Mikalauskiene have nothing to declare in relation to this article. Review Process: Double-blind peer review. Compliance with Ethics: This study involves a review of the literature and did not involve any studies with human or animal subjects performed by any of the authors.

Access: This article is freely accessible at tOuchOPHTHALMOLOGY.COM.

(C) Touch Medical Media 2019.

Authorship: The named authors meet the International Committee of Medical Journal Editors (ICMJE) criteria for authorship of this manuscript, take responsibility for the integrity of the work as a whole, and have given final approval for the version to be published.

Received: 29 May 2019

Accepted: 5 August 2019

Citation: European Ophthalmic Review. 2019;13(1): 37-43

Corresponding Author: Andrzej Grzybowski, Department of Ophthalmology, Poznan' City Hospital, 3 Szwajcarska St, 361-285 Poznań, Poland. E: ae.grzybowski@gmail.com

Support: No funding was received in the publication of this article.
Various options for the prevention of pseudophakic cystoid macular oedema (PCMO) have been offered. Nonsteroidal anti-inflammatory drugs (NSAIDS) seem to be beneficial in preventing postoperative inflammation; however, there is lack of evidence for long-term benefit after cataract surgery. What is more, topical NSAID preparations are difficult to compare, as studies differ in inclusion criteria, patient characteristics, prescription and duration of treatment. There is ongoing discussion whether NSAIDS and corticosteroids have an additive or synergistic effect. In this article, we provide an up-to-date review of the different strategies used for the prevention of PCMO. Pubmed and Cochrane Library were used to search for studies published up to 1 May 2019. We used key search terms, such as 'pseudophakic cystic macular edema', 'post-operative inflammation', 'cataract surgery' and 'nonsteroidal anti-inflammatory drugs'. Reference lists of identified studies were also searched. We included only articles that had abstracts in English language. Relevant information from selected textbooks was also included. We analysed and compared studies to create an overview of PCMO with focus on the prevention.

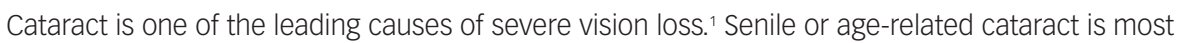
common type so the prevalence rate increases as the population ages. ${ }^{2}$ It is possible to restore vision in patients with cataracts by removing the opacification of the lens. Cataract surgery is a widely used procedure considered to be safe and effective. Due to mechanical damage implicated in the surgery and reaction to the artificial intraocular lens and other non-infectious substances entering the eye during surgery, various level of inflammation may occur. ${ }^{3}$ Surgical trauma causes the release of prostaglandins (Figure 1), which affect the eye structures and mediate inflammatory reactions. Prostaglandins increase vascular permeability and dilation, and white blood cell reaction and migration. Postoperative inflammation is quite a common reaction, although untreated might cause complications - formation of the synechiae, corneal oedema, elevation of intraocular pressure (IOP), cystoid macular oedema. ${ }^{4}$ Patient discomfort, pain, delayed recovery and suboptimal visual outcome after cataract surgery can be caused by uncontrolled inflammation. ${ }^{5}$ Inflammation of the eye and excreted prostaglandins can also cause smooth muscle contraction in the iris which leads to miosis during surgery. ${ }^{6}$

The exact pathogenesis of PCMO remains unclear, although it is thought to be multifactorial. It is known that surgical manipulation in the anterior chamber may cause the release of arachidonic

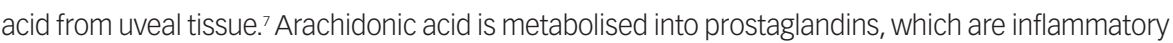
mediators that cause swelling of the fovea by increasing vascular permeability and fluid accumulation due to the breakdown of the blood-aqueous and blood-retinal barriers., PCMO is thought to be a common cause of unsatisfactory functional outcome with a prevalence ranging from $0.10-2.35 \%$. ${ }^{9}$ Incidence of PCMO depends on how cystoid macular oedema is defined. ${ }^{6}$ In patients who are not diabetic and without ocular risk factors, such as iris trauma and vitreous loss, the incidence is $1.17 \% .{ }^{10}$ Not all cases of PCMO experience functional impairment, and these are called sub-clinical PCMO. Conversely those eyes with visual impairment are designated clinically significant. 
Figure 1: Pseudophakic cystoid macular oedema

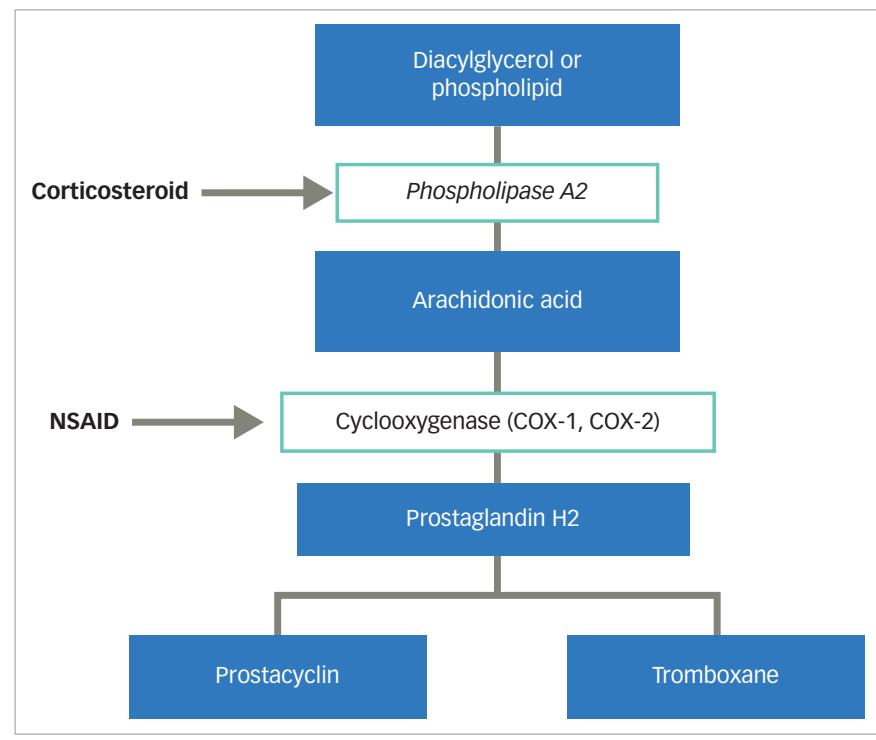

NSAID = nonsteroidal anti-inflammatory.

A decrease in visual acuity is not always present, but fluorescein angiography can show evidence of macular oedema. The presence of PCMO can be determined by using optical coherence tomography (OCT) - diagnostic tool that allows objective measurement of changes in retina volume. The incidence of PCMO defined by OCT after uncomplicated phacoemulsification in a recent study was found to be $2.72 \% .{ }^{11}$ Usually mild subclinical episodes of PCMO resolve spontaneously. ${ }^{12}$ Lobo et al. have shown that macular oedema reaches a maximum at 6 weeks, after which, most cases led to recovery; although seven eyes (22\%) still had macular oedema in 30 weeks. ${ }^{13}$ Henderson et al. reported that $\mathrm{PCMO}$ in patients after cataract surgery resolved in $249.0 \pm 2.8$ days with no treatment, and that patients treated with combined NSAIDs and corticosteroids had significantly shorter resolution times of $82.6 \pm 56.9$ days. ${ }^{14}$ Most reports favour treatment for cases of clinically significant $\mathrm{PCMO}$ to prevent irreversible damage to the macula. ${ }^{6}$

\section{Pseudophakic cystoid macular oedema risk factors}

PCMO may occur in healthy eyes without risk factors after uncomplicated cataract surgery, although it is more often in contralateral PCMO, diabetes mellitus, uveitis, retinal vein occlusion, retinal degeneration, macular degeneration, radiation retinopathy, epiretinal membranes, choroidal tumours and aging ${ }^{10,15-17}$ Patients with diabetes, even without diabetic retinopathy, have increased risk in developing PCMO after cataract surgery, as poor glycaemic control is associated with a risk of postoperative macular edema. ${ }^{18}$ Accumulation of inflammatory cytokine concentrations in ocular tissues may contribute to early neuronal cell death in the retina. ${ }^{19}$ Hyperglycaemia increases concentration of circulating cytokines due to oxidation mechanisms. ${ }^{20}$ Raised levels of inflammatory and proliferative factors may contribute to pathogenesis of proliferative diabetic retinopathy (PDR) and even correlate with the severity of PDR (interleukin 6 [IL-6], vascular endothelial growth factor [VEGF], transforming growth factor [TGF $\beta-1]$ ). ${ }^{18,21}$ Risk of PCMO was found to be proportionate to the severity of diabetic retinopathy. ${ }^{10}$ In a multicentre database study was conducted by Denniston et al. which included patients undergoing cataract surgery with diabetes and no history of diabetic macular oedema. In the first year after surgery risk of developing diabetic macular oedema which required treatment was $1.0 \%$ for patients with no diabetic retinopathy preoperatively, $5.4 \%$ for patients with mild non-proliferative diabetic retinopathy (NPDR), 10.0\% for moderate, and $13.1 \%$ for severe NPDR. ${ }^{22}$ In a study conducted by Yang et al., risk factors for PCMO after cataract surgery were duration, severity and type of diabetes; hardness of the lens; and glycated haemoglobin (HDA1C) levels. ${ }^{23}$ Patient allergy and atopy have not been found to increase the risk of $\mathrm{PCMO}^{24}$

\section{Nonsteroidal anti-inflammatory drugs}

NSAIDs are chemical compounds, which inhibit cyclooxygenase (COX) enzymes and therefore inhibit the synthesis of prostaglandins. ${ }^{4}$ The US Food and Drug Administration (FDA) approved the following topical NSAIDS: nepafenac, bromfenac, ketorolac, diclofenac and flurbiprofen (Table 1). Indications for use of them are inflammation and pain associated with cataract surgery, corneal refractive surgery, inhibition of intraoperative miosis and seasonal allergic conjunctivitis. ${ }^{25}$ NSAIDS are not FDA indicated for the treatment of PCMO; however, they may be beneficial in increasing the speed of visual recovery in the first several weeks after cataract surgery.12 Topical NSAIDs may cause some side effects such as transient burning, punctate keratitis and corneal epithelial defects. ${ }^{4,26}$ NSAIDs may cause cytotoxic reactions which can lead to significant corneal alterations such as corneal melts. ${ }^{27}$

\section{Diclofenac}

Diclofenac sodium $0.1 \%$ is a derivative of phenyl acetic acid and one of the most commonly used NSAIDs. In randomised controlled trial, Medić et al. showed significantly lower IL-12 levels in the aqueous humour of patients with diabetic retinopathy using diclofenac $0.1 \%$ four times a day for 7 days, compared to placebo. The same study compared central foveal thickness 30 days after surgery in two groups treated with either diclofenac $0.1 \%$ or dexamethasone $0.1 \%$, and reported lower incidence of postoperative macular oedema in the NSAID group. ${ }^{27} \mathrm{~A}$ combination of cyclodextrin (cyclic oligosaccharide) with diclofenac may lower ocular toxicity and enhance corneal tolerability. ${ }^{28}$

\section{Nepafenac}

Nepafenac is a potent prodrug which is converted to its active metabolite, amfenac, by intraocular hydrolases. ${ }^{29}$ Amfenac suppresses prostaglandin synthesis by inhibiting COX-1 and COX-2. In study conducted by Walters et al., amfenac showed greater potency at COX-2 inhibition than ketorolac $0.4 \%$ and bromfenac $0.09 \%{ }^{30}$ Nepafenac $0.1 \%$ is also considered to be safe on the ocular surface after surgery. In a prospective randomised trial, postoperative corneal staining was compared when using nepafenac $0.1 \%$ or diclofenac $0.1 \%$ beginning 3 hours before surgery and three times a day for 4 weeks postoperatively. Patients in the diclofenac group had significantly higher corneal staining scores 4 weeks postoperatively. ${ }^{31}$ Tzelikis et al. reported nepafenac $0.3 \%$ once daily, starting 2 days before surgery and 5 weeks after, was effective in reducing macular thickness compared to placebo, although without a difference in visual acuity (all patients received prednisolone acetate for 5 weeks postoperatively). ${ }^{32}$

\section{Bromfenac}

Bromfenac is an NSAID which is available in different concentrations: $0.07 \%, 0.075 \%$ and $0.09 \%$. It is used to treat postoperative inflammation and ocular pain after cataract surgery, although it is not indicated for the prevention or treatment of PCMO. ${ }^{33}$ Bromfenac $0.09 \%$ has good ocular penetration properties and has been found to maintain stable concentration in the aqueous humour up to 12 hours after instillation. ${ }^{34}$ Bromfenac $0.07 \%$ and $0.09 \%$ ocular distribution were compared in a 12-hour study with rabbits, and no significant difference in ocular tissue between concentrations was found. ${ }^{35}$ Bromfenac $0.075 \%$ (BromSite ${ }^{\oplus}$; Sun Ophthalmics, Princeton New Jersey, USA) is relatively new compound 
Table 1: US Food and Drug Administration approved topical nonsteroidal anti-inflammatory drugs

\begin{tabular}{|l|l|l|l|l|}
\hline Drug & Concentration & Pharmacokinetics ${ }^{4}$ & Pharmacodynamics \\
\hline Nepafenac & $0.1-0.3 \%$ & Reaches peak aqueous concentration $205.3 \mathrm{ng} / \mathrm{mL}$ in 30 minutes & potent inhibitor of COX-2 \\
\hline Bromfenac & $0.07 \%, 0.075 \%, 0.09 \%$ & Reaches peak aqueous concentration $25.9 \mathrm{ng} / \mathrm{mL}$ in 240 minutes & potent inhibitor of COX-2 \\
\hline Ketorolac & $0.5 \%$ & Reaches peak aqueous concentration $57.5 \mathrm{ng} / \mathrm{mL}$ in 60 minutes & most potent inhibitor of COX-1 \\
\hline Diclofenac & $0.1 \%$ & Reaches peak aqueous concentration $82.0 \mathrm{ng} / \mathrm{mL}$ in 2.4 hours & No information available \\
\hline Flurbiprofen & $0.03 \%$ & Reaches peak aqueous concentration $60.0 \mathrm{ng} / \mathrm{mL}$ in 2.0 hours & No information available \\
\hline
\end{tabular}

Table 2: Corticosteroids

\begin{tabular}{|c|c|c|c|c|}
\hline Drug & Concentration & Permeability & $\begin{array}{l}\text { Bioavailability } \\
(\mathrm{mcg} / \mathrm{min} / \mathrm{g})^{45}\end{array}$ & $\begin{array}{l}\text { Anti-inflammatory } \\
\text { efficacy }(\%)^{45}\end{array}$ \\
\hline Dexamethasone & $0.1 \%$ & $\begin{array}{l}\text { After topical instillation, the drug can be found in } \\
\text { aqueous humour, vitreous, blood serum; } 44 \\
\text { Suspension gives three times higher concentration } \\
\text { in aqueous humour than solution }{ }^{45}\end{array}$ & 111 & 55 \\
\hline Prednisolone & $1.0 \%$ & Reaches aqueous humour ${ }^{45}$ & 2.395 & 51 \\
\hline Loteprednol & $0.5 \%$ & Reaches aqueous humour, iris, ciliary body ${ }^{49}$ & Information not available & Information not available \\
\hline Fluorometholone & $0.1-0.25 \%$ & $\begin{array}{l}\text { Low aqueous solubility, } \\
\text { does not reach anterior chamber, low accumulation } \\
\text { in the tissues }{ }^{71}\end{array}$ & Information not available & Information not available \\
\hline Difluprednate & $0.05 \%$ & $\begin{array}{l}\text { Reaches aqueous humour and iris/ciliary body } \\
\text { tissues }^{72}\end{array}$ & Information not available & Information not available \\
\hline
\end{tabular}

formulated with the DuraSite ${ }^{\circledast}$ delivery system (Sun Ophthalmics), a mucoadhesive matrix contributing to longer ocular surface dwelling time. ${ }^{25}$ Sheppard et al. conducted an in vivo study with rabbits, comparing the pharmacokinetics of bromfenac $0.075 \%$, bromfenac $0.7 \%$ and nepafenac/amfenac $0.3 \%$ ophthalmic solutions. This study showed similar ocular distribution patterns in both the anterior and posterior segments, although bromfenac $0.075 \%$ (Bromsite) showed significantly higher concentrations in ocular tissues. ${ }^{25}$ In an ex vivo study performed in human aqueous humour, bromfenac concentration was significantly higher in subjects receiving DuraSite containing bromfenac $0.075 \%$ than bromfenac $0.09 \%$ after 3 days of dosing. ${ }^{36}$

In several studies, bromfenac was shown to be quite well tolerated. In a study conducted by Chinchurreta Capote et al., none of the patients complained of eye stickiness when using bromfenac compared to $13.8 \%$ of patients in nepafenac group and $10.3 \%$ of patients treated with diclofenac sodium. This observational comparative study using post-surgical satisfaction questionnaire showed that bromfenac is well tolerated; moreover, bromfenac was found to be more effective than diclofenac and nepafenac in reducing PCMO after phacoemulsification. ${ }^{37}$ In another randomised controlled study, bromfenac $0.09 \%$ was also found to be better tolerated than diclofenac $0.1 \%$; although diclofenac appeared to be more effective in reducing postoperative inflammation in terms of anterior chamber laser flare-cell photometry and central foveal thickness. ${ }^{38}$

\section{Ketorolac}

Ketorolac tromethamine is a NSAID, usually used to manage pain, including during eye surgery. Ketorolac tromethamine $0.5 \%$ has been shown to be equally effective as diclofenac sodium $0.1 \%$ in reducing the severity and duration of PCMO after cataract surgery. ${ }^{39}$ Ketorolac $0.045 \%$ ophthalmic solution containing carboxymethylcellulose was developed relatively recently. Attar et al. reported that formulation of ketorolac $0.045 \%$, pH 6.8 , increased the bioavailability in aqueous humour and iris-ciliary body more so than ketorolac $0.4 \%, \mathrm{pH} 7.4 .^{40}$ Waterbury et al. reported higher concentrations of ketorolac $0.045 \%$ in animal ocular tissues than bromfenac $0.09 \% .{ }^{41}$

\section{Corticosteroids}

Corticosteroids act as phospholipase-A2 inhibitors and prevent the release of arachidonic acid which can be metabolised to leukotrienes and prostaglandins. (Table 2$)^{42}$ This class of drugs also prevent epithelial adhesion, chemotaxis, phagocytosis.12 Adverse effects of topical corticosteroids use include IOP elevation, impaired wound healing, infection and development of cataracts. ${ }^{43}$

\section{Dexamethasone}

Dexamethasone eye drops may be applied topically after cataract surgery. Dexamethasone disodium phosphate eye drops have been found to have low penetration to aqueous humour and vitreous compared to other administration routes (peribulbar or subconjunctival injection). ${ }^{44}$ Dexamethasone disodium phosphate suspension gives three-times higher concentration in the aqueous humour when applied topically compared to dexamethasone solution. ${ }^{45}$ In a randomised, doubleblind, prospective study, Ylinen et al. showed that dexamethasone monotherapy ( $1 \mathrm{mg} / \mathrm{mL}$ three times a day for 3 weeks) after cataract surgery had lower effect compared to diclofenac $(1 \mathrm{mg} / \mathrm{mL}$ three times a day for 3 weeks) or dexamethasone and diclofenac. ${ }^{46}$ No significant difference in preventing PCMO was found when comparing postoperative use of prednisolone acetate to dexamethasone phosphate. ${ }^{47}$ Klamann et al. showed that an intravitreal $0.7 \mathrm{mg}$ dexamethasone implant may be effective in postoperative macular oedema treatment. ${ }^{48}$

\section{Prednisolone}

Prednisolone acetate $1.0 \%$ is one of the most frequently used corticosteroids after cataract surgery. Prednisolone is a synthetic analogue of the glucocorticoid hydrocortisone. It has good ocular penetration characteristics and is relatively the most effective antiinflammatory agent for anterior segment ocular inflammation. ${ }^{49}$ 


\section{Difluprednate}

Difluprednate or difluoroprednisolone butyrate acetate are modifications of prednisolone to increase its potency - affinity for the glucocorticoid receptor and enhance tissue penetration. It was approved by FDA in $2008,{ }^{50}$ and is available in $0.05 \%$ ophthalmic solution. Garg et al. reported 0.05 difluprednate used six times a day for 4 weeks compared to prednisolone acetate $1.0 \%$ six times a day for 4 weeks is equally effective in treatment of postoperative inflammation. ${ }^{51}$ In a retrospective study, Tijunelis et al. reported no significant difference in IOP change between two groups of patients using difluprednate twice a day for 30 days and prednisolone acetate four times a day for 30 days after cataract surgery. ${ }^{50}$

\section{Triamcinolone acetonide}

Subconjunctival triamcinolone acetonide may provide a prolonged antiinflammatory effect after cataract surgery. Lindholm et al. reported a good effect on postoperative central retinal thickness and aqueous flare of $20 \mathrm{mg}(0.5 \mathrm{~mL} ; 40 \mathrm{mg} / \mathrm{mL})$ with a perioperative subconjunctival injection of triamcinolone acetonide after cataract surgery, compared to daily dexamethasone $1 \mathrm{mg} / \mathrm{mL}$ three times a day for 3 weeks. No serious adverse events were observed in 90-day period..$^{52}$ Yüksel et al. compared $40 \mathrm{mg}$ sub-Tenon triamcinolone acetonide injection to twice-daily topical nepafenac $0.1 \%$ and found that both treatment modalities are effective; although nepafenac was more efficacious in terms of visual gain. ${ }^{53}$ In a randomised controlled trial, PREMED Study Report 2, subconjunctival injection of $40 \mathrm{mg}$ triamcinolone acetonide was used as additional treatment for diabetic patients undergoing phacoemulsification cataract surgery. Macular thickness and macular volume were found to be lower at weeks 6 and 12, postoperatively, in patients who received triamcinolone than patients who did not. ${ }^{54}$

\section{Prevention of pseudophakic cystoid macular oedema}

Due to spontaneous resolution of most uncomplicated PCMO cases, practice patterns of PCMO prevention differ. There is an opinion that prophylaxis of PCMO is unnecessary if patients have no risk factors. ${ }^{55}$ Cataractsurgery guidelines from the AmericanAcademy of Ophthalmology (AAO) recommend using NSAIDs only in high-risk cases, such as diabetic retinopathy. ${ }^{56}$ The National Institute for Health and Care Excellence (NICE) recommends to consider using a combination of topical steroids and NSAIDS after cataract surgery for people with increased risk of PCMO, for example, patients with diabetes or uveitis. Topical steroids and/or NSAIDs may be offered after cataract surgery to prevent inflammation and $\mathrm{PCMO} .{ }^{57}$ The Canadian Ophthalmology Society recommends using topical steroids, NSAIDs or both in all intraocular surgery. ${ }^{58}$

Inflammation after cataract surgery may be controlled using topical NSAIDS or steroids (Table 3). Kessel et al. performed a systematic literature review and found that topical NSAIDs are more effective than topical steroids, and therefore recommend using them to prevent PCMO after cataract surgery. ${ }^{8}$ Although, this review was criticised for not discussing studies in which no difference in macular volume was found when comparing NSAIDs and placebo, and not including existing recommendations for the prevention of postoperative inflammation and PCMO.59 Moreover, a Cochrane systematic review has shown that value of using NSAIDS as an alternative to, or in combination with, topical steroids to prevent vision loss after cataract surgery, is uncertain. ${ }^{60}$

Almeida et al. evaluated the efficacy of ketorolac $0.5 \%$ versus nepafenac $0.1 \%$ on macular volume 1 month after cataract surgery. Patients were divided in three groups and received ketorolac $0.5 \%$, nepafenac $0.1 \%$ or placebo. Patients were instructed to instil one drop four times a day, 1 day preoperatively and for 4 weeks postoperatively. All patients received prednisolone $1.0 \%$ for 4 weeks. No significant difference in central subfield thickness postoperatively was found between the groups ${ }^{61}$

Ramakrishnan et al. compared the effects of $0.1 \%$ nepafenac and $0.4 \%$ ketorolac on central macular thickness after cataract surgery. Both groups received prednisolone $1.0 \%$ one month postoperatively and NSAID drops three times a day 1 day preoperatively and 30 days postoperatively. Central macular thickness 1 month postoperatively was not significant differently. ${ }^{62}$

There are studies showing the superior effect of NSAIDs in combination with steroids than steroids alone. Zaczek et al. compared two groups of patients, one received nepafenac $0.1 \%$ three times a day starting 2 days preoperatively and continued 3 weeks after and dexamethasone $0.1 \%$ three times a day for 3 weeks after cataract surgery, and other group received dexamethasone $0.1 \%$ alone. The combination of NSAID and steroid was found to have greater effect on reducing subclinical macular swelling than steroid alone. ${ }^{63}$

Jung et al. reported a beneficial effect of bromfenac $0.1 \%$ (one drop twice daily starting 3 days before cataract surgery and for 4 weeks postoperatively) or ketorolac $0.45 \%$ (one drop twice daily starting 1 day before surgery and continuing 2 weeks postoperatively) compared to prednisolone alone after cataract surgery in reducing postoperative inflammation and macular changes. All patients in the three groups received topical gatifloxacin $0.3 \%$ and prednisolone acetate $1.0 \%$ for 4 weeks postoperatively. ${ }^{64}$ In another study conducted by Pollack et al. patients were randomised to two groups, the first group using nepafenac $0.1 \%$ three times daily starting 1 day before surgery and 90 days after; and the second group using vehicle. Both groups of patients received dexamethasone $0.1 \%$ four times daily for 2 weeks postoperatively. The NSAID-steroid combination group showed a significantly lower percentage of eyes developing macular oedema within 90 days after cataract surgery.5 Campa et al. found that bromfenac 0.09\% (one drop two times a day for 3 days before surgery and 15 days after) or nepafenac $0.01 \%$ (one drop three times a day for 3 days before surgery and 4 weeks after) usage with dexamethasone sodium phosphate $1.32 \mathrm{mg}$ and netilmicin sulphate $4.55 \mathrm{mg}$ (four times daily for 4 weeks after surgery) are associated with reduced incidence of PCMO than using dexamethasone alone. ${ }^{66}$ Toyos compared two groups of patients undergoing phacoemulsification using only once-daily bromfenac $0.07 \%$ or nepafenac $0.3 \%$ solutions and found no significant difference in terms of retinal thickness increase. ${ }^{67}$

Randomised controlled clinical trial PREMED (the prevention of macular oedema after cataract surgery) compared different prevention methods in patients without (PREMED Study Report 1) and with (PREMED Study report 2) diabetes across 12 European study centers. Study Report 1 compared NSAID, corticosteroids and their combination in the prevention of PCMO in nondiabetic patients after cataract surgery. There were three groups of patients: the first one received bromfenac 0.09\% twice daily 2 days preoperatively and 2 weeks postoperatively, second group received dexamethasone $0.1 \% 4$ times daily 2 days preoperatively and 2 weeks postoperatively, third group used combination of these two drugs. Patients underwent ophthalmologic examination at baseline and had follow-up visits at 6 and 12 weeks postoperatively. The study results showed that patients who received combination of bromfenac $0.09 \%$ and dexamethasone $0.1 \%$ had lowest postoperative macular thickness and the risk of developing clinically significant PCMO was 
Table 3: Topical nonsterioidal anti-inflammatory drugs or steroids used after surgery

\begin{tabular}{|c|c|c|c|c|c|c|}
\hline Treatment & Reference (eyes) & NSAID group & Dosage & Control group & Additional group & Results \\
\hline $\begin{array}{l}\text { NSAID vS } \\
\text { placebo } \\
\text { (+ steroid) }\end{array}$ & $\begin{array}{l}\text { Medić et al. }^{27} \\
\text { (55 patients with } \\
\text { type } 2 \text { diabetes) }\end{array}$ & Diclofenac 0.1\% & $\begin{array}{l}\text { Four times daily } 7 \text { days } \\
\text { preoperatively and } \\
30 \text { days postoperatively }\end{array}$ & $\begin{array}{l}\text { Placebo } 7 \text { days } \\
\text { preoperatively and } \\
\text { dexamethasone } 0.1 \% \\
30 \text { days postoperatively }\end{array}$ & NA & $\begin{array}{l}\text { Smaller increase in } \\
\text { CFT in NSAID group, } \\
p<0.001\end{array}$ \\
\hline $\begin{array}{l}\text { NSAID + steroid } \\
\text { vs } \\
\text { placebo + } \\
\text { steroid }\end{array}$ & $\begin{array}{l}\text { Tzelikis et al. }{ }^{32} \\
\text { (224 eyes of } 112 \\
\text { patients) }\end{array}$ & $\begin{array}{l}\text { Nepafenac } 0.3 \% \\
\text { (with } \\
\text { prednisolone } \\
1.0 \% 5 \text { weeks } \\
\text { after surgery) }\end{array}$ & $\begin{array}{l}\text { Once daily for } 2 \text { days } \\
\text { preoperatively and } \\
5 \text { weeks postoperatively }\end{array}$ & $\begin{array}{l}\text { Artificial tear substitute } \\
\text { for } 2 \text { days preoperatively } \\
\text { and } 5 \text { weeks } \\
\text { postoperatively } \\
\text { (with prednisolone } 1.0 \% \\
5 \text { weeks postoperatively) }\end{array}$ & NA & $\begin{array}{l}\text { Central subfield } \\
\text { thickness significantly } \\
\text { lower in NSAID group, } \\
p=0.01\end{array}$ \\
\hline $\begin{array}{l}\text { NSAID vS } \\
\text { steroid vs } \\
\text { combination }\end{array}$ & $\begin{array}{l}\text { Ylinen et al. }{ }^{46} \\
\text { (189 eyes of } 180 \\
\text { patients) }\end{array}$ & Diclofenac 0.1\% & $\begin{array}{l}\text { Three times daily for } \\
3 \text { weeks postoperatively }\end{array}$ & $\begin{array}{l}\text { Dexamethasone } 0.1 \% \\
\text { three times daily and } \\
\text { Diclofenac } 0.1 \% \text { three } \\
\text { times daily }\end{array}$ & $\begin{array}{l}\text { Dexamethasone } 0.1 \% \\
\text { three times daily }\end{array}$ & $\begin{array}{l}\text { Central retinal } \\
\text { thickness was } \\
\text { smallest in diclofenac } \\
\text { and dexamethasone } \\
\text { group, } p<0.001\end{array}$ \\
\hline $\begin{array}{l}\text { NSAID + steroid } \\
\text { Vs NSAID + } \\
\text { steroid vs } \\
\text { steroid }\end{array}$ & $\begin{array}{l}\text { Jung et al. }{ }^{64} \\
\text { (91 subjects) }\end{array}$ & $\begin{array}{l}\text { Bromfenac } 0.1 \% \\
\text { (with } \\
\text { prednisolone } \\
1.0 \% 4 \text { weeks } \\
\text { after surgery) }\end{array}$ & $\begin{array}{l}\text { Twice daily for } 3 \text { days } \\
\text { preoperatively and } \\
4 \text { weeks postoperatively }\end{array}$ & $\begin{array}{l}\text { Prednisolone } 1.0 \% \\
4 \text { weeks postoperatively }\end{array}$ & $\begin{array}{l}\text { Ketorolac } 0.45 \% 2 \text { days } \\
\text { preoperatively and } \\
2 \text { weeks postoperatively } \\
\text { (with prednisolone } \\
1.0 \% 4 \text { weeks } \\
\text { postoperatively) }\end{array}$ & $\begin{array}{l}\text { Central foveal subfield } \\
\text { thickness was similar } \\
\text { among the groups, } \\
p=0.648\end{array}$ \\
\hline $\begin{array}{l}\text { NSAID + steroid } \\
\text { vs vehicle + } \\
\text { steroid }\end{array}$ & $\begin{array}{l}\text { Pollack et al. }{ }^{65} \\
\text { (175 patients with } \\
\text { nonproliferative } \\
\text { diabetic } \\
\text { retinopathy) }\end{array}$ & Nepafenac 0.1\% & $\begin{array}{l}\text { Three times daily for } \\
90 \text { days postoperatively } \\
\text { (+dexamethasone } 0.1 \% \\
4 \text { times daily } 2 \text { weeks } \\
\text { postoperatively) }\end{array}$ & $\begin{array}{l}\text { Vehicle three times } \\
\text { daily for } 90 \text { days } \\
\text { postoperatively } \\
\text { (+dexamethasone } 0.1 \% \\
\text { four times daily } 2 \text { weeks } \\
\text { postoperatively) }\end{array}$ & NA & $\begin{array}{l}\text { A significantly greater } \\
\text { percentage in vehicle } \\
\text { group developed } \\
\text { macular oedema } \\
\text { within } 90 \text { days } \\
\text { postoperatively, than } \\
\text { in nepafenac group, } \\
p=0.01\end{array}$ \\
\hline $\begin{array}{l}\text { NSAID + steroid } \\
\text { vs NSAID + } \\
\text { steroid vs } \\
\text { steroid }\end{array}$ & $\begin{array}{l}\text { Campa et al. }{ }^{66} \\
\text { (144 patients) }\end{array}$ & $\begin{array}{l}\text { Bromfenac } \\
0.09 \%\end{array}$ & $\begin{array}{l}\text { Twice daily for } 3 \text { days } \\
\text { preoperatively and } \\
15 \text { days postoperatively } \\
\text { (+dexamethasone } \\
1.32 \text { mg four times daily } \\
\text { for } 4 \text { weeks) }\end{array}$ & $\begin{array}{l}\text { Dexamethasone sodium } \\
\text { phosphate } 1.32 \text { mg four } \\
\text { times daily for } 4 \text { weeks }\end{array}$ & $\begin{array}{l}\text { Nepafenac } 0.1 \% \text { three } \\
\text { times daily for } 3 \text { days } \\
\text { preoperatively and } \\
5 \text { weeks postoperatively } \\
\text { (+dexamethasone } \\
1.32 \text { mg four times daily } \\
\text { for } 4 \text { weeks) }\end{array}$ & $\begin{array}{l}\text { Central subfield } \\
\text { thickness higher (after } \\
5 \text { weeks) in control } \\
\text { group, although not } \\
\text { significantly different, } \\
\text { p=0.22 }\end{array}$ \\
\hline NSAID VS NSAID & $\begin{array}{l}\text { Ylinen et al. }{ }^{55} \\
\text { (96 eyes of } 95 \\
\text { patients) }\end{array}$ & $\begin{array}{l}\text { Nepafenac } \\
1 \mathrm{mg} / \mathrm{mL}\end{array}$ & $\begin{array}{l}\text { Three times daily for } \\
3 \text { weeks postoperatively }\end{array}$ & $\begin{array}{l}\text { Diclofenac } 1 \mathrm{mg} / \mathrm{mL} \\
3 \text { times daily for } 3 \text { weeks }\end{array}$ & NA & $\begin{array}{l}\text { Central retinal } \\
\text { thickness (in } 28 \text { days) } \\
\text { was not significantly } \\
\text { different, } p=0.327\end{array}$ \\
\hline $\begin{array}{l}\text { NSAID + steroid } \\
\text { vs NSAID + } \\
\text { steroid vs } \\
\text { placebo + } \\
\text { steroid }\end{array}$ & $\begin{array}{l}\text { Almeida et al. }{ }^{61} \\
\text { (162 patients) }\end{array}$ & Nepafenac 0.1\% & $\begin{array}{l}\text { Four times daily for } \\
1 \text { day preoperatively and } \\
4 \text { weeks postoperatively } \\
\text { (+prednisolone } 1.0 \% \text { for } \\
4 \text { weeks) }\end{array}$ & $\begin{array}{l}\text { Placebo four times daily } \\
1 \text { day preoperatively and } \\
4 \text { weeks postoperatively } \\
\text { (+prednisolone } 1.0 \% \text { for } \\
4 \text { weeks) }\end{array}$ & $\begin{array}{l}\text { Ketorolac } 0.5 \% \\
\text { Four times daily } 1 \text { day } \\
\text { preoperatively and } \\
4 \text { weeks postoperatively } \\
\text { (+prednisolone } 1.0 \% \text { for } \\
4 \text { weeks) }\end{array}$ & $\begin{array}{l}\text { No statistically } \\
\text { significant difference } \\
\text { between groups } \\
\text { in central subfield } \\
\text { thickness, } p=0.291\end{array}$ \\
\hline $\begin{array}{l}\text { NSAID + steroid } \\
\text { vs placebo + } \\
\text { steroid }\end{array}$ & $\begin{array}{l}\text { Zaczek et al. }{ }^{63} \\
\text { (152 patients) }\end{array}$ & Nepafenac 0.1\% & $\begin{array}{l}\text { Three times daily for } \\
2 \text { days preoperatively and } \\
3 \text { weeks postoperatively } \\
\text { (+dexamethasone } 0.1 \% \\
\text { three times daily for } \\
3 \text { weeks postoperatively) }\end{array}$ & $\begin{array}{l}\text { Placebo three } \\
\text { times daily } 2 \text { days } \\
\text { preoperatively and } \\
3 \text { weeks postoperatively } \\
\text { (+dexamethasone } 0.1 \% \\
\text { three times daily for } \\
3 \text { weeks postoperatively) }\end{array}$ & NA & $\begin{array}{l}\text { Total macular volume } \\
\text { was significantly } \\
\text { lower } 3 \text { weeks } \\
\text { postoperatively in } \\
\text { nepafenac group, } \\
p=0.032\end{array}$ \\
\hline $\begin{array}{l}\text { NSAID + steroid } \\
\text { Vs NSAID + } \\
\text { steroid }\end{array}$ & $\begin{array}{l}\text { Ramakrishnan } \\
\text { et al. }{ }^{62} \\
\text { (200 eyes of } 200 \\
\text { patients) }\end{array}$ & Nepafenac 0.1\% & $\begin{array}{l}\text { Three times daily } 1 \text { day } \\
\text { preoperatively and } 3 \\
\text { weeks postoperatively } \\
\text { (+prednisolone } 1.0 \% \text { for } \\
4 \text { weeks) }\end{array}$ & $\begin{array}{l}\text { Ketorolac } 0.4 \% \\
\text { three times daily } 1 \text { day } \\
\text { preoperatively and } \\
3 \text { weeks postoperatively } \\
\text { (+prednisolone } 1.0 \% \text { for } \\
4 \text { weeks) }\end{array}$ & - & $\begin{array}{l}\text { Central macular } \\
\text { thickness at } 1 \text { month } \\
\text { postoperatively was } \\
\text { not significantly } \\
\text { different, } p=0.43\end{array}$ \\
\hline
\end{tabular}

CFT = central foveal thickness; NA = not applicable. 
lower than in patients treated only with bromfenac or dexamethasone. Visual acuity between the groups were not significantly different at 6 and 12 weeks postoperatively. Although PCMO incidence, which developed at 6 weeks postoperatively in most cases, was significantly lowest in combination group. ${ }^{68}$

InPREMEDStudy Report2, all patients who underwent phacoemulsification received treatment with bromfenac and dexamethasone eyedrops. Patients were allocated into four groups according to the additional treatment they received. The first group were prescribed subconjunctival injection of triamcinolone acetonide, the second group received intravitreal injection of bevacizumab, the third group received both medications, and the fourth group got no additional treatment. ${ }^{57}$ Almost all patients included in the study were diagnosed with diabetes mellitus and most of them had no signs of diabetic retinopathy at the time of surgery. An extensive ophthalmologic examination was performed on the study eye, including subjective refraction, corrected distance visual acuity, slit lamp examination, tonometry, fundoscopic examination and macular thickness measurements using OCT. Patients had follow-up visits 6 and 12 weeks postoperatively and underwent ophthalmologic examination. The results of this trial show that patients who had subconjunctival injection of triamcinolone acetate postoperatively had lower mean central subfield macular thickness than patients who had not had triamcinolone acetate. Additionally, none of patients in this treatment group developed cystoid macular oedema. Although, IOP was significantly higher in patients who received the subconjunctival injection of triamcinolone acetate than patients in other groups. However, based on the results of the PREMED study, triamcinolone acetate injections are not recommended for all diabetic patients undergoing cataract surgery considering the low overall incidence of postoperative PCMO and increased IOP. ${ }^{54}$

None of these studies demonstrate a significant effect on visual acuity over longer periods ( $>3$ months) after cataract surgery. Kim et al. performed literature review on the effectiveness of topical NSAIDs in preventing PCMO. They concluded that there is a lack of level 1 evidence to support the long-term efficacy of NSAIDs in preventing vision loss for $>3$ months after surgery; however, NSAIDs may improve the speed of visual recovery postoperatively.12 Pollack et al. analysed the change in best corrected visual acuity from baseline to day 90 after cataract surgery and found that the change was greater in the nepafenac group than in the vehicle group, although it was not statistically significant. ${ }^{65}$

There is an ongoing debate about cost-benefit ratio regarding prevention of PCMO. ${ }^{4}$ PCMO treatment usually involves more invasive methods, which may cost more than prevention. ${ }^{69}$ Schmier et al. found that patients who are treated for PCMO in the USA have higher Medicare claims than patients who do not develop PCMO. Of 78,949 patients who underwent cataract surgery, $2.54 \%(n=2,003)$ were diagnosed with PCMO. Ophthalmic charges were significantly higher for patients who developed PCMO (US $\$ 10,410$ versus $\$ 5,950$ ). Targeting interventions for high-risk patients are likely to be more cost-effective. ${ }^{70}$

\section{Conclusions}

Inflammation after cataract surgery remains an important cause of postoperative complications, such as intraoperative miosis, anterior uveitis, ocular hypertension or PCMO, even when using modern surgery methods. PCMO usually resolves spontaneously, although may cause a decrease in visual acuity and damage the macula when untreated. Postoperative inflammation of the eye can be relieved by steroids and/ or NSAIDs. These two classes of drugs have overlapping mechanisms of action. It is not yet verified if the interaction between these drugs is synergistic or additive. Based on the present accumulation of evidence the combination of steroids and NSAIDs in the perioperative period lead to benefits in visual acuity during 12 weeks after standard cataract surgery; however, this effect disappears after this period. On the other hand, combination therapy brings clear benefits in PCMO prevention in high-risk cataract cases in both short-term and long-term follow ups.
1. Song $\mathrm{P}$, Wang $\mathrm{H}$, Theodoratou $\mathrm{E}$, et al. The national and subnational prevalence of cataract and cataract blindness in China: a systematic review and meta-analysis. I Glob Health 2018;8:010804.

2. Melancia D, Pinto A, Marques-Neves C. Cataract surgery and intraocular pressure. Ophthalmic Res. 2015:53:141-8.

3. Duan P, Liu Y, Li J. The comparative efficacy and safety of topical non-steroidal anti-inflammatory drugs for the treatment topical non-steroidal anti-inflammatory drugs for the treatm of anterior chamber intammation after cataract surgery: a systematic review and network meta-analysis. Graefes Arch

4. Kim SJ, Fach AJ, Jampol LM. Nonsteroidal anti-inflammatory drugs in ophthalmology. Surv Ophthalmol. 2010;55:108-33.

5. Colin J. The role of NSAIDs in the management of postoperative ophthalmic inflammation. Drugs. 2007;67:1291-308.

6. Hoffman RS, Braga-mele R, Donaldson $\mathrm{K}$, et al. Cataract surgery and nonsteroidal antiinflammatory drugs. $J$ Cart Refract Surg. 2016;42:1368-79.

7. Grzybowski A, Kanclerz P. Assessing the impact of FLACS on surgical outcomes. Modern Retina from Ophthalmology Times. Available at: www.modernretina.com modern-retina/assessing-impact-flacs-surgical-outcomes (accessed 7 August 2019).

8. Flesner P, Andresen JL, Hjortdal J. Post-cataract Prevention of Inflammation and Inflammation and Macular Edema by Steroid and Nonsteroidal Anti-inflammatory Eye Drops. Ophthalmology. 2014;121:1915-

9. Do JR, Oh J, Chuck RS, Park CY. Transient corneal edema is a predictive factor for pseudophakic cystoid macular edema after uncomplicated cataract surgery. Korean J Ophthalmol. 2015;29:14-22.

10. Chu CJ, Johnston RL, Buscombe $C$, et al. Risk factors and incidence of macular edema after cataract surgery a database study of 81984 Eyes. Ophthalmology. 2016;123:316-23.

11. Yoon DH, Kang DJ, Kim MJ, Kim HK. New observation of microcystic macular edema as a mild form of cystoid macular lesions after standard phacoemulsification. Medicine (Baltimore). 2018;97:e0355.

12. Kim SJ, Schoenberger SD, Thorne JE, et al. Topical nonsteroidal anti-inflammatory drugs and cataract surgery. Ophthalmology. 2015;122:2159-68.
13. Lobo CL, Faria PM, Soares MA, et al. Macular alterations after small-incision cataract surgery. I Cataract Refract Surgery. 2004;30:752-60.

14. Henderson BA, Kim JY, Ament CS, et al. Clinical pseudophakic cystoid macular edema. J Cataract Refract Surg. 2007;33:1550-8.

15. McCafferty S, Harris A, Kew C, et al. Pseudophakic cystoid macular edema prevention and risk factors; prospective study with adjunctive once daily topical nepafenac $0.3 \%$ versus placebo. BMC Ophthalmol. 2017;17:16.

16. Schaub F, Adler W, Enders P, et al. Preexisting epiretina

membrane is associated with pseudophakic cystoid membrane is associated with pseudophakic cystoid
macular edema. Graefe's Arch Clin Exp Ophthalmol. macular edema.

17. Cho HJ, Hwang HJ, Kim HS, et al. Macular edema after cataract
Cho surgery in eyes with preoperative retinal vein occlusion. Retin 2018;38:1180-6.

18. Ylinen P, Laine I, Lindholm J-M, Tuuminen R. Poor glycemic control as a risk factor for pseudophakic cystoid macular edema in patients with diabetes. J Cataract Refract Surg. 2017;43:1376-82

19. Rübsam $A$, Parikh S, Fort PE. Role of inflammation in diabetic retinopathy. Int J Mol Sci. 2018;19:942.

20. Esposito K, Nappo F, Marfella R, et al. Inflammatory cytokine concentrations are acutely increased by hyperglycemia in humans role of oxidative stress. Circulation. 2002;106:2067-72

21. Rusnak S, Vrzalova J, Sobotova M, et al. The measurement of intraocular biomarkers in various stages of proliferative diabetic retinopathy using multiplex Xmap technology. J Ophthalmol. 2015;2015:424783.

22. Denniston AK, Chakravarthy U, Zhu H, et al. The UK Diabetic Retinopathy Electronic Medical Record (UK DR EMR) Users Group, Report 2: real-world data for the impact of cataract surgery on diabetic macular oedema. Br J Ophthalmol. 2017;101:1673-8.

23. Yang J, Cai L, Sun Z, et al. Risk factors for and diagnosis of pseudophakic cystoid macular edema after cataract surgery in diabetic patients. I Cart Refract Surg. 2017;43:207-14.

24. Schaub F, Adler W, Koenig MC, et al. Impact of allergy and atop on the risk of pseudophakic cystoid macular edema. Graefe's Arch Clin Exp Ophthalmol. 2016;254:2417-23.
25. Sheppard JD, Cockrum PC, Justice A, Jasek MC. In vivo pharmacokinetics of bromfenac ophthalmic solution $0.075 \%$, bromfenac ophthalmic solution $0.07 \%$, and nepafenac/amfenac ophthalmic suspension $0.3 \%$ in rabbits. Ophthalmol Ther. 2018;7:157-65

26. Miyake K. Four decades of topical nonsteroidal antiinflammatory drugs use: Current issues and controversies. J Cart Refract Surg. 2018;44:421-3.

27. Medić A, Jukić T, Matas A, et al. Effect of preoperative topical diclofenac on intraocular interleukin-12 concentration and macular edema after cataract surgery in patients with diabetic retinopathy : a randomized controlled trial. Croat Med $\rfloor$. 2017:58:49-55.

28. Abdelkader $\mathrm{H}$, Fathalla Z, Moharram $\mathrm{H}$, et al. Cyclodextrin enhances corneal tolerability and reduces ocular toxicity caused by diclofenac. Oxid Med Cell Longev. 2018;2018:5260976

29. Yanni SE, Clark ML, Yang R, et al. The effects of nepafenac and amfenac on retinal angiogenesis. Brain Res Bull. 2010;81:310-9.

30. Walters T, Raizman M, Ernest P, Gayton J, Lehmann R. In vivo pharmacokinetics and in vitro pharmacodynamics of nepafenac, amfenac, ketorolac, and bromfenac. J Cataract Refract Surg. 2007;33:1539-1545.

31. Kawahara A, Utsunomiya $\mathrm{T}$, Kato $\mathrm{Y}$, Takayanagi Y. Comparison of effect of nepafenac and diclofenac ophthalmic solutions on cornea, tear film, and ocular surface after cataract surgery: the results of a randomized trial. Clin Ophthalmol. 2016;10:385-91.

32. Tzelikis PF, Morato CS, Neves NT, et al. Intraindividual comparison of nepafenac $0.3 \%$ for the prevention of macular edema after phacoemulsification. J Cataract Refract Surgery. 2018;44:440-6.

33. Sheppard JD. Topical bromfenac for prevention and treatment of cystoid macular edema following cataract surgery: a review. Clin Ophthalmol. 2016:10:2099-111.

34. Vagge A, Salis A, Fucile C, et al. Bromfenac ophthalmic solution $0.09 \%$ : human aqueous humor concentration detected by high-performance liquid chromatography. Int Ophthalmol. 2017:37:417-21.

35. Baklayan GA, Muñoz M. The ocular distribution of 14C-labeled 
bromfenac ophthalmic solution $0.07 \%$ in a rabbit model. Clin Ophthalmol. 2014;8:1717-24.

36. Walters TR, Smyth-Medina RJ, Paul CC. An ex vivo human aqueous humor-concentration comparison of two commercial bromfenac formulations. Clin Ophthalmol. 2018:12:943-7.

37. Chinchurreta Capote AM, Lorenzo Soto M, Rivas Ruiz F, et al. Comparative study of the efficacy and safety of bromfenac, nepafenac and diclofenac sodium for the prevention of cystoid macular edema after phacoemulsification. Int J Ophthalmol. 2018;11:1210-6.

38. Giannaccare G, Finzi A, Sebastiani S, et al. The Comparative Efficacy and Tolerability of Solutions after Cataract Surgery. Curt Eye Res. 2018;43:1445-1453.

39. Rho DS. Treatment of acute pseudophakic cystoid macular edema: Diclofenac versus ketorolac. I Cataract Refract Surg. 2003;29:2378-84

40. Attar M, Schiffman R, Borbridge L, et al. Ocular pharmacokinetics of $0.45 \%$ ketorolac tromethamine. Clin Ophthalmol. 2010;4:1403-8.

41. Waterbury LD, Galindo D, Villanueva L, et al. Ocular penetration and anti-inflammatory activity of ketorolac $0.45 \%$ and bromfenac $0.09 \%$ against lipopolysaccharide-induced inflammation. J Ocul Pharmacol Ther. 2011;27:173-8.

2. Juthani W, Clearfield E, Chuck RS. Non-steroidal antinflammatory drugs versus corticosteroids for controlling inflammation after uncomplicated cataract surgery. Cochrane Database Syst Rev. 2017;7:CD010516.

43. Guo S, Patel S, Baumrind B, et al. Management of pseudophakic cystoid macular edema. Surv Ophthalmol. 2015;60:123-37.

44. Weijtens O, Schoemaker RC, Romijn FP, et al. Intraocula penetration and systemic absorption after topical application of dexamethasone disodium phosphate. Ophthalmology. 2002;109:1887-91.

45. Cagini $\mathrm{C}$, Cometa F, Torroni $\mathrm{G}$, et al. Dexamethasone disodium phosphate penetration into the human aqueous humor after topical application. Curr Eye Res. 2016:41:897-9.

46. Ylinen P, Holmstrom E, Laine I, Lindholm J-M, Tuuminen R. Anti-inflammatory medication following cataract surgery: a randomized trial between preservative- free dexamethasone diclofenac and their combination. Acta Ophthalmol. 2018:96:486-493.

47. Baartman BJ, Gans R, Goshe J. Prednisolone versus dexamethasone for prevention of pseudophakic cystoid macular edema. Can J Ophthalmol. 2018;53:131-4.

48. Klamann A, Böttcher K, Ackermann P, et al. Intravitreal dexamethasone implant for the treatment of postoperative macular edema. Ophthalmologica. 2016;236:181-5.
49. Sendrowski DP. Anti-Inflammatory Drugs. In: Fiscella RG, Holdeman NR, Prokopich CL. Clinical Ocular Pharmacology. Elsevier Inc., 2008;221-44.

50. Tijunelis MA, Person E, Niziol LM, et al. Comparison of prednisolone acetate $1.0 \%$ and difluprednate ophthalmic emulsion $0.05 \%$ after cataract surgery: Incidence of postoperative steroid-induced ocular hypertension. $J$ Cart Refract Surg. 2017;43:223-7.

51. Garg P, Tuteja N, Qayum S. To study the efficacy of difluprednate ophthalmic emulsion and prednisolone acetate ophthalmic suspension on post- operative inflammation in cataract surgery. J Clin Diagn Res. 2016;10:NC05-8.

52. Lindholm JM, Taipale $C$, Ylinen P, Tuuminen R. Perioperative subconjunctival triamcinolone acetonide injection for treatment of inflammation and macular edema after cataract surgery. Acta Ophthalmol 2019: doi:10.1111/aos.14175 [Epub ahead of print].

53. Yüksel B, Uzunel UD, Kerci SG, et al. Comparison of subtenon triamcinolone acetonide injection with topical nepafenac for the treatment of pseudophakic cystoid macular edema. Ocul the treatment of pseudophakic cys
Immunol Inflamm. 2017:25:513-9.

54. Wielders LHP, Schouten JSAG, Winkens B, et al. Randomized controlled European multicenter trial on the prevention of cystoid macular edema after cataract surgery in diabetics: ESCRS PREMED Study Report 2. J Cataract Refract Surg. 2018;44:836-47

55. Ylinen P, Taipale $\mathrm{C}$, Lindholm J. Postoperative management in cataract surgery: nepafenac and preservative-free diclofenac compared. Acta Ophthalmol. 2018;96:853-9.

56. Olson RJ, Braga-Mele R, Chen SH. Cataract in the adult eye Preferred Practice Pattern ${ }^{\oplus}$. Ophthalmology. 2017:124:P1-119

57. National Institute for Health and Care Excellence. Cataracts in adults: management. NICE Guideline [NG77] 2017. Available at: www.nice.org.uk/guidance/ng77 (accessed 7 August 2019).

58. Tsangaridou M, Grzybowski A, Gundlach E Pleyer U. Controversies in NSAIDS use in cataract surgery.

59. Grzybowski A. Re: Kessel et al.: post-cataract prevention of inflammation and macular edema by steroid and nonsteroidal anti-inflammatory eye drops: a systematic review (Ophthalmology 2014;121:1915-24). Ophthalmology. 2015;122:e16-7.

60. Lim BX, Lim CH, Lim DK, et al. Prophylactic non-steroida anti-inflammatory drugs for the prevention of macular oedema after cataract surgery. Cochrane Database Syst Rev. 2016;11:CD006683.

61. Almeida DR, Khan Z, Xing $L$, et al. Prophylactic nepafenac and ketorolac versus placebo in preventing postoperative macular edema after uneventful phacoemulsification J Cataract Refract Surg. 2012:38:1537-43.

62. Ramakrishnan S, Baskaran P Talwar B, venkatesh R. Prospective, randomized study comparing the effect of $0.1 \%$ nepafonac and $0.4 \%$ ketorolac tromethamine on macular thickness in cataract surgery patients with low risk for cystoid macular edema. Asia Pac J Ophthalmol (Phila). 2015;4:216-20

63. Zaczek A, Artzen D, Laurell C, Stenevi U. Nepafenac $0.1 \%$ plus dexamethasone $0.1 \%$ versus dexamethasone alone: Effect on macular swelling after cataract surgery. I Cataract Refract Surgery. 2014;40:1498-505

64. Jung JW, Chung BH, Kim EK, et al. The effects of two non-steroidal anti-inflammatory drugs, bromfenac $0.1 \%$ and ketorolac $0.45 \%$, on cataract surgery. Yonsei Med J. 2015;56:1671-7.

65. Pollack A, Staurenghi G, Sager D, et al. Prospective randomised clinical trial to evaluate the safety and efficacy of nepafenac $0.1 \%$ treatment for the prevention of macular oedema associated with cataract surgery in patients with diabetic retinopathy. Br J Ophthalmol. 2017;101:423-7.

66. Campa C, Salsini G, Perri P, et al. Comparison of the efficacy of dexamethasone, nepafenac, and bromfenac for preventing pseudophakic cystoid macular edema: an open-label, prospective, randomized controlled trial. Curr Eye Res. 2018;43:362-7.

67. Toyos MM. Comparison of once-daily bromfenac $0.07 \%$ versus once-daily nepafenac $0.3 \%$ in patients undergoing phacoemulsification. Ophthalmol Ther. 2019;8:261-70.

68. Wielders LHP, Schouten JSAG, Winkens B, et al. European multicenter trial of the prevention of cystoid macular edema after cataract surgery in nondiabetics: ESCRS PREMED study report 1. J Cataract Refract Surg. 2018;44:429-39.

69. Bora Yüksel, Ömer Karti, Kusbeci T. Topical nepafenac for prevention of post-cataract surgery macular edema in diabetic patients : patient selection and perspectives. Clin Ophthalmol. 2017:2183-2190.

70. Schmier JK, Covert DW, Hulme-Lowe CK, et al. Treatment costs of cystoid macular edema among patients following cataract of cystoid macular edema among patie
surgery. Clin Ophthalmol. 2016:477-83.

71. Noh G, Keum T, Seo J, Choi J, Rakesh B. Development and Evaluation of a Water Soluble Fluorometholone Eye Drop Formulation Employing Polymeric Micelle. Pharm. 2018;10:E208

72. Tajika T, Waki M, Tsuzuki M, Kida T, Sakaki H. Pharmacokinetic Features of Difluprednate Ophthalmic Emulsion in Rabbits as Determined by Glucocorticoid Receptor-Binding Bioassay. J Ocul Pharmacol Ther. 2011;27:29-3. 